\title{
WebGIS for communicating Alpine ecosystem services: stakeholder engagement in Slovenian protected areas
}

\author{
Annemarie Polderman, Suzana Vurunić, Nadine Houbé, Oliver Bender \& Andreas Haller
}

Keywords: information and communication technologies, public participation, resource use, Alpine Space programme

\section{Abstract}

The Alpine Space project AlpES used a web-based Geographic Information System (WebGIS) to communicate knowledge on Alpine ecosystem services to stakeholders from three protected areas in Slovenia to support more sustainable decision-making. This has been a positive experience, yet some shortcomings became evident. In this report we focus on using stakeholders' technical experiences, needs and knowledge to develop a WebGIS, and on communicating project results to stakeholders. We address some critical issues related to co-designing a WebGIS. We provide recommendations to more fully achieve the potential of a WebGIS as a tool for knowledge transfer.

\section{Introduction}

The establishment and management of protected mountain areas is a complex process which often causes conflicts over natural resources (see Badola \& Hussain 2003; Braun et al. 2018; Haller \& CórdovaAguilar 2018, Thomas \& Middleton 2003). To deal with these complexities and lessen conflicts over natural resources, many European protected mountain areas seek to increase the participation of local people and communities in planning and the management of natural resources. This trend towards inclusive processes is also noticeable in many projects funded by the European Commission, in which stakeholder engagement, co-design and knowledge transfer have become established components. In addition, in recent decades a number of information and communication technologies have been developed and tested, including decision support tools (see Grêt-Regamey et al. 2017; Hewitt \& Macleod 2017; Bagstad et al. 2013). Using the example of ecosystem services (ES) in Slovenian protected areas, in this paper we discuss stakeholder engagement and knowledge transfer using a web-based Geographic Information System (WebGIS) within the context of an Interreg Alpine Space Programme project. With an emphasis on technical considerations, we focus on using stakeholders' technical experiences, needs and knowledge to inform the development of the WebGIS, and on communicating the project results to stakeholders. We conclude this report with a discussion of the advantages, disadvantages, opportunities and challenges of a WebGIS as a tool for knowledge transfer and decision support. We also provide several recommendations for future project activities, with a special focus on protected areas.

\section{The AlpES project}

Through the Interreg Alpine Space Programme, the European Regional Development Fund (ERDF) places a high value on stakeholder engagement activities, co-design of project activities and project outputs, and tailored knowledge transfer to stakeholder groups. The emphasis on stakeholder engagement, co-design and knowledge transfer is in line with a wider tendency within other funding programmes of the European Commission (see e.g. Interreg Alpine Space n.d. and European Commission 2018). That is why stakeholder involvement and the development of an interactive WebGIS were important elements of the EU project Alpine Ecosystem Services - Mapping, Maintenance, Management, or AlpES for short. The focus of this project was raising awareness of, and communicating, the potential of the concept of ES to public authorities, policy makers, NGOs and economic actors, including those who are working in protected areas. The application of the ES concept is discussed increasingly in Alpine protected areas, partly due to the increasingly popular but controversial idea of payments for ES (see Schomers \& Matzdorf 2013).

Ten project partners from six Alpine countries (Austria, France, Germany, Italy, Liechtenstein and Slovenia) carried out the project. The partners collected, analysed and distributed information about Alpine ES at municipal level, with the aims of introducing a common understanding of ES as a regional and transnational environmental governance framework, and of training and supporting the AlpES target groups to understand, value and manage these services. The project consortium chose to build a WebGIS, since such a tool is the easiest and cheapest way to make spatial project results available to a broad audience. The Institute for Interdisciplinary Mountain Research (IGF), a research establishment of the Austrian Academy of Sciences (ÖAW), was responsible for the development of the WebGIS and for coordinating the expansion of the wiki-style Alpine knowledge platform WIKIAlps within the project (see www.alpes-webgis.eu and www. wikialps.eu).

\section{Stakeholder involvement in AlpES}

The objectives of the stakeholder involvement meetings were to inform stakeholders personally about 


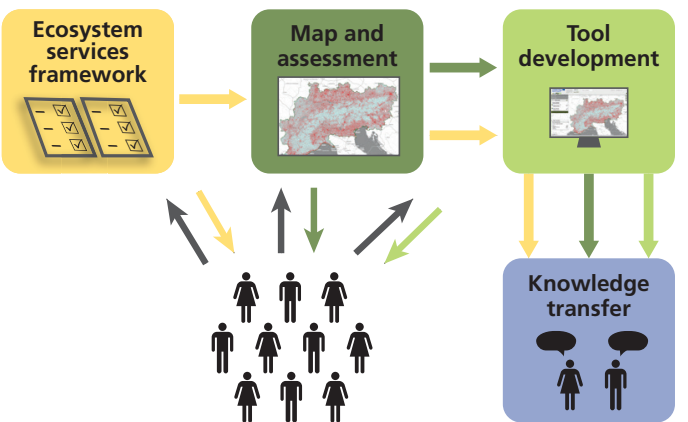

Figure 1 - Communication flows during the WebGIS development (adapted from AlpES website).

the intermediate results of WIKIAlps and WebGIS, and to obtain their feedback for the further development of the WebGIS and WIKIAlps (see Figure 1).

The AlpES project partners involved 23 stakeholders in the WebGIS and WIKIAlps. Most stakeholders worked for a public authority, followed by nongovernmental organizations, and small or medium enterprises. Many stakeholders, who included managers from protected mountain areas in France, Germany and Slovenia, were involved in project management, natural resource management, and policy planning. We asked stakeholders to rate and give feedback for various functions and aspects of the AlpES WebGIS and WIKIAlps.

\section{Case studies: protected areas in Slovenia}

The Institute of the Republic of Slovenia for Nature Conservation (IRSNC), which is an AlpES partner and one of the main players in the field of nature conservation in Slovenia, carried out many of its project activities in the Primorsko-Notranjska NUTS 3 (statistical) region. This is a diverse area, with high levels of biodiversity (large carnivores, preserved forests, extensive cultural landscapes) and considerable potential for sustainable development. The IRSNC highlighted the usefulness of the ES concept for environmental management and spatial planning in its stakeholder involvement activities, focusing in particular on the theory behind the ES concepts, and on the WebGIS and its indicators and maps as a useful tool for sustainable development.

Three major protected areas are located in the Primorsko-Notranjska region (see Table 1): (1) the Seasonal Lakes of Pivka Landscape Park, (2) the Notranjska Regional Park, and (3) the Škocjan Caves Regional Park and its buffer zones.

The Seasonal Lakes of Pivka Landscape Park is the most recently established park in the region. It was established in 2014 by the municipality of Pivka; $99 \%$ of its area is part of the Natura 2000 network. Its most recognizable karst features are 17 intermittent lakes. The Notranjska Regional Park lies within the municipality of Cerknica and is characterized by a unique combination of diverse landscapes, the interaction be-

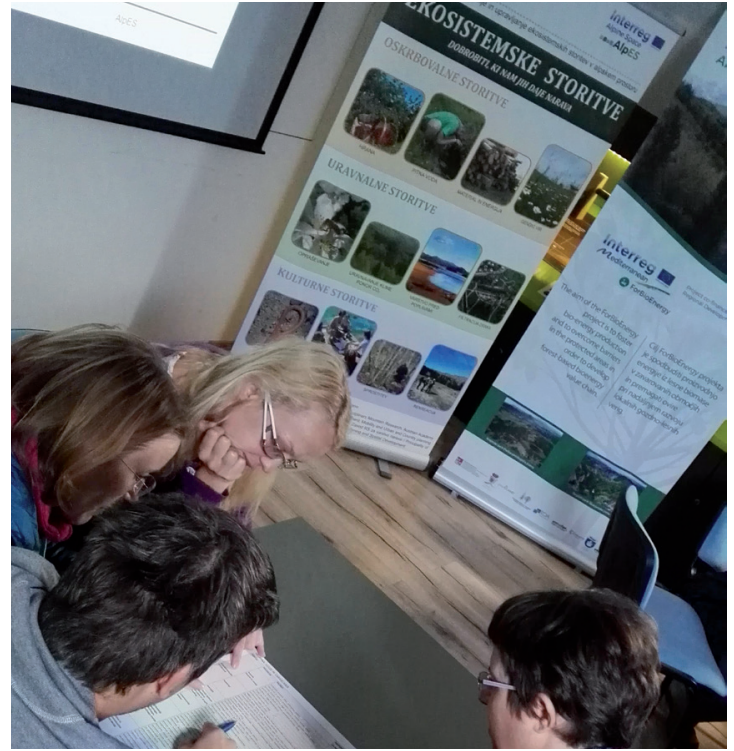

Figure 2 - Stakeholder training in the Pivka Park ecomuseum. (C) IRSNC

tween culture and nature, and a large number of Karst phenomena. The park is listed as a Ramsar site and has nine Natura 2000 areas. A central role is safeguarding the intermittent Lake Cerknica, which appears each year on the karst polje (plain). The Škocjan Caves Regional Park is a narrow protected area that encompasses the area above the Škocjan Caves, the Reka River Gorge and the surrounding collapsed dolines. The park is listed in the Ramsar directory and is part of UNESCO's Man and the Biosphere Programme (Debevec \& Kranjc 2019). For further information, the reader is referred to the parks' respective websites.

\section{Slovenian stakeholder involvement}

Throughout the project, the IRSNC had many face-to-face meetings, workshops, phone conversations and email exchanges with stakeholders involved in the three protected areas. Among the stakeholders were the Municipality of Pivka, the Seasonal Lakes of Pivka Landscape Park (see Figure 2), the local development centre of Pivka, the Regional Development Agency Green Karst, BOREO (the Regional Focal Point for NGOs), the Notranjska Regional Park, the Križna Cave Association, the Karst Research Institute Postojna, and the Slovenian Forest Service. The majority of the stakeholders were local and regional actors, but some were also involved at national level.

The WebGIS and WIKIAlps platform were introduced to all Slovenian stakeholders via different means of communication. The IRSNC had promoted their usefulness from the outset, when the WebGIS tool was equipped with only basic maps, to the final stage, when all AlpES ES maps where uploaded into the WebGIS and the background information became available on the wiki platform. One interviewee stated that the display of attributes is 
Table 1 - Overview on the three case studies in protected areas in Slovenia. Source: wmw.protectedplanet.net and the parks' websites.

\begin{tabular}{|l|l|l|l|}
\hline Protected area & Seasonal Lakes of Pivka Landscape Park & Notranjska Regional Park & Škocjan Caves Regional Park \\
\hline Original name & Krajinski park Pivška presihajoča jezera & Notranjski regijski park & Regijski park Škocjanske jame \\
\hline Area & $137.83 \mathrm{~km}^{2}$ & $222.84 \mathrm{~km}^{2}$ & $4.13 \mathrm{~km}^{2}$ (core area); $450 \mathrm{~km}^{2}$ (buffer zone) \\
\hline $\begin{array}{l}\text { English } \\
\text { designation }\end{array}$ & Landscape Park & $\begin{array}{l}\text { Regional Park and Ramsar } \\
\text { Directory of Wetlands }\end{array}$ & $\begin{array}{l}\text { Regional Park, Ramsar Directory of Wet- } \\
\text { lands, Man and the Biosphere Programme } \\
\text { (World Network of Biosphere Reserves), and } \\
\text { World Heritage Site (natural) }\end{array}$ \\
\hline Year of designation & 2014 & 2002 & 1986 \\
\hline Characteristics & Intermittent lakes; karst landscape & $\begin{array}{l}\text { Rich natural and cultural } \\
\text { heritage; karst landscape }\end{array}$ & $\begin{array}{l}\text { Cave system of global significance; karst } \\
\text { landscape }\end{array}$ \\
\hline
\end{tabular}

"Useful, easy; but there could be an explanation for each individual parameter so that the user knows exactly what itmeans."

The stakeholder feedback was then analysed and taken into consideration during the further development of the tools. Overall, stakeholders welcomed such tools, because they provided them with easy access to the AlpES results and in particular to the indicator maps, as well as to the indicators' metadata and general descriptions. Stakeholders were interested in the status of ES at the Alpine level as well as within the Primorsko-Notranjska region specifically. In addition, inter-regional differences regarding the values of ecosystem service indicators were of particular interest to the stakeholders. This information was considered useful for spatial planning purposes, as illustrated one stakeholder's response to the question How useful might the AlpES WebGIS become for your work?:

"The AlpES WebGIS could provide an overview of the ES present in our park and comparison with other areas. The comparison would help us in spatial planning."

While most stakeholders from protected areas knew of the ES concept (and some even used it in practice for communication purposes), others were less familiar with it. However, they all questioned the concept's use- fulness for their work, or proposed developing the ES concept further in order to turn it into an understandable tool for a wide audience (with easily understandable maps, for example). The various degrees of familiarity with the ES concept among stakeholders was evident when discussing the usefulness of the concept or when comparing the ecosystem service indicator maps with the actual situations in their respective areas. A limited understanding of the ES concept seemed to hamper some stakeholders' ability to use the WebGIS in a meaningful way. However, most stakeholders involved in the management of the three protected areas had a good understanding of the ecosystem service concept and faced fewer problems making meaningful maps and interpreting them correctly, indicating successful knowledge transfer. (For an example of an ES indicator map of the Slovenian test region, see Figure 3.) Nevertheless, they did not consider the maps to be very useful for park-related planning and management purposes, since the indicators were calculated at municipality level. Stakeholders therefore often suggested making ecosystem service data available at a higher resolution in the WebGIS.

The IRSNC collaborated most intensively with stakeholders from the Municipality of Pivka, the Seasonal Lakes of Pivka Landscape Park (see Figure 4), and the local development centre of Pivka, which followed the development of the tools closely and gave

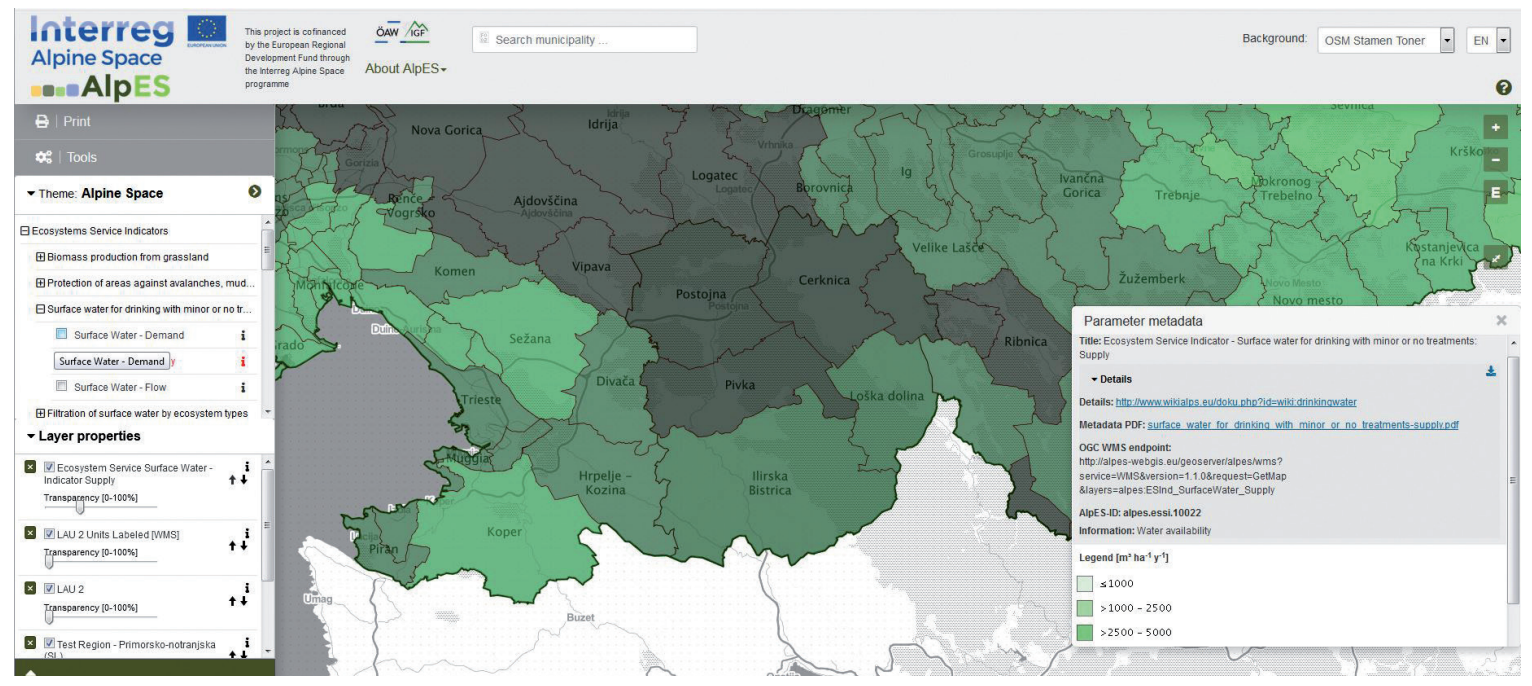

Figure 3 - Screenshot of the AlpES WebGIS. 


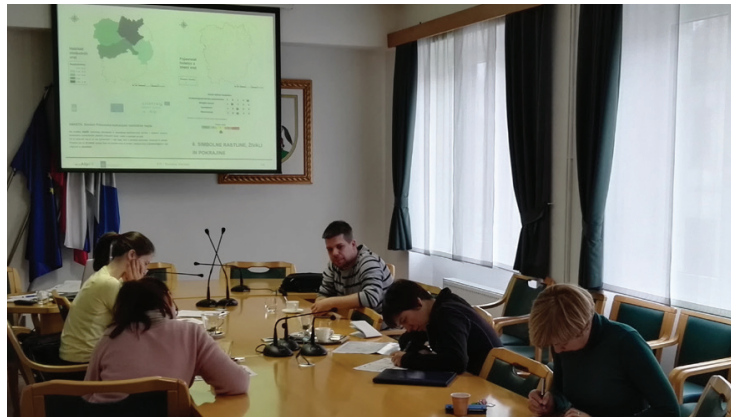

Figure 4 - Meeting with representatives of the Municipality of Pivka and the Seasonal Lakes of Pivka Landscape Park. (C) IRSNC

their feedback via a questionnaire or in personal communications. Stakeholders valued the multilingual aspect of the WebGIS, which allowed them to navigate the tool in their own language. Stakeholders also gave a high rating to the ease of navigating the WebGIS, even without much GIS experience. IGF was able to incorporate a substantial number of the stakeholders' suggestions for improvement into the WebGIS (e. g. a search button for municipalities, a direct zoom into the test regions, and satellite imagery), and into the WIKIAlps (e.g. changes to the menu, and adding non-English content).

Not all suggestions for improvements could be integrated, either because they were technically not feasible within the duration of the project, or because they were outside the scope of the project. Examples of the former were suggestions to develop a WebGIS function to compare selected municipalities and ecosystem service indicators, and to provide the possibility for users to upload their own data sets into the WebGIS. The suggestion, already mentioned above, to upload ecosystem service indicators with a higher resolution than the municipal level into the WebGIS was outside the scope of the project, since higher-resolution data was not available for the whole Alpine space.

\section{Take-home messages}

Almost five years ago, in an article on Web 2.0 technologies for sustainable regional development in the European Alps, Borsdorf et al. (2015) concluded that the possibilities of web-based instruments had not been fully explored.

Developing a WebGIS to communicate spatial project results of spatial projects to stakeholders has many advantages. For one, users of a WebGIS only need a web browser and internet connection to be able to access the WebGIS. Since the AlpES WebGIS is open source, there is no need to buy software packages. Using open source software also limits project expenditure, which is a positive in a publicly funded project.

There are, however, also some critical issues related to the use of a WebGIS as a means of communicating knowledge on Alpine ES. The first is that for a Web-
GIS to be an effective tool for knowledge transfer, a certain level of computer literacy and basic GIS and cartographic knowledge are required. Furthermore, spatial data is often difficult to interpret, despite the availability of metadata information. A prerequisite for the correct interpretation of spatial data is a good understanding by the user of the concept behind the integrated data, in this case ES. Another issue is that users want to use a WebGIS for a variety of purposes. These purposes may not be in line with the objectives that the data developer, WebGIS developer and the project partnership decided upon earlier in the project. A more practical issue involves dealing with stakeholders' high and sometimes unrealistic expectations and their wide-ranging requests regarding WebGIS data availability, user interface and features.

We have several recommendations to address the critical issues and challenges outlined above. Providing a comprehensive tutorial on how to use the WebGIS should give users the necessary information and ability to use the WebGIS in a meaningful way. During the development phase of the WebGIS, stakeholders should be continuously engaged in order to gather feedback on matters such as user interface, WebGIS features, and understandability of metadata information. The aims and scope of the project need to be clearly communicated early on to stakeholders, so that unrealistic expectations can be avoided. Ideally, stakeholders should be consulted in the project preparation phase to ensure that their needs are incorporated in the project design. Close collaboration between data developer and WebGIS developer is necessary in order to achieve spatial data results that are easily understandable and usable by the project's target groups. This needs to be complemented by stakeholder engagement activities to obtain feedback regarding the interpretation of the data.

The AlpES WebGIS and its associated wiki-style platform WIKIAlps were developed with the aim of making spatial project results available to the AlpES target groups in order to support more sustainable decision-making. Managers of protected areas can use these tools to communicate with other stakeholders in protected areas in order to find common ground regarding natural resources management in general and ES provision in particular, thus reducing conflicts over natural resources. However, for a web-based GIS application, such as the AlpES WebGIS, to fully achieve its potential as an effective tool for knowledge transfer and supporting sustainable decision making, it is important to take the critical issues discussed above into account. This is by no means intended as a discouragement for using a web-based GIS application in future projects. Being able to visualize spatial project results in a WebGIS is a powerful asset and the recommendations given above can be implemented relatively easy if they are taken into account early in the project preparation stage. 


\section{References}

Badola, R. \& S.A. Hussain 2003. Conflict in Paradise: Women and Protected Areas in the Indian Himalayas. Mountain Research and Development 23: 234-237.

Bagstad, K.J., D.J. Semmens, S. Waage \& R. Winthrop 2013. A comparative assessment of decisionsupport tools for ecosystem services quantification and valuation. Ecosystem Services 5: 27-39.

Borsdorf, A., O. Bender, F. Braun \& A. Haller 2015. Web-based instruments for strengthening sustainable regional development in the Alps. Acta geographica Slovenica 55: 173-182. DOI: 10.3986/AGS.897

Braun, V., G. Bendler, A. Haller \& K. Heinrich 2018. Timelines of Tension: Trajectories of ProtectedArea Creation in the Austrian Alps. Journal of Alpine Research | Revue de Géographie Alpine 106: 1-20. DOI: 10.4000/rga.4711

Debevec, V. \& D. Kranjc 2019. The Karst Biosphere Reserve in Slovenia. eco.mont - Journal on protected mountain areas and research and management 11(2): 43-49. DOI: 10.1553/eco.mont-11-2s43

European Commission 2018. A renewed European Agenda for Research and Innovation - Europe's chance to shape its future. COM (2018) 306 final. Available at: https://ec.europa.eu/info/publications/renewedeuropean-agenda-research-and-innovation-europeschance-shape-its-future_en (accessed on 25/06/2019)

Grêt-Regamey, A., E. Sirén, S.H. Brunner \& B. Weibel 2017. Review of decision support tools to operationalize the ecosystem services concept. Ecosystem Services 26: 306-315. DOI: 10.1016/j.ecoser.2016.10.012

Haller, A. \& H. Córdova-Aguilar 2018. Urbanization and the advent of regional conservation: Huancayo and the Cordillera Huaytapallana, Peru. eco.mont - Journal on protected mountain areas and research and management 10(2): 59-63. DOI: 10.1553/eco.mont-10-2s59

Hewitt, R.J. \& C.J.A. Macleod 2017. What Do Users Really Need? Participatory Development of Decision Support Tools for Environmental Management Based on Outcomes. Environments 4(4): 88. DOI: 10.3390/environments 4040088

Interreg Alpine Space (n.d). Corporation Programme Alpine Space 2014-2020. Available at: https://www.alpine-space.eu/about/programmedocuments/asp_cooperation_programme_final.pdf (accessed on 25/06/2019)

Interreg Europe (n.d). Use of ICT in protection of natural and cultural heritage. Available at: https://www. interregeurope.eu/policylearning/news/1675/useof-ict-in-protection-of-natural-and-cultural-heritage/ (accessed on 07/06/2019)

Notranjska Regional Park (n.d.). Available at: https://web.archive.org/web/20190529081404/ https://www.notranjski-park.si/en (accessed on 12/04/2019)

Seasonal Lakes of Pivka Landscape Park (n.d.). Available at: https://web.archive.org/ web/20180801142446/http://www.pivskajezera. si:80/index.php?jez=SLO (accessed on 12/04/2019)

Schomers, S. \& B. Matzdorf 2013. Payments for ecosystem services: A review and comparison of developing and industrialized countries. Ecosystem Services 6: 16-30. DOI: 10.1016/j.ecoser.2013.01.002

Škocjan Caves Regional Park (n.d.). Available at: https://web.archive.org/web/20190602154150/ https://www.park-skocjanske-jame.si/en/ (accessed on $12 / 04 / 2019)$

Thomas, L. \& J. Middleton 2003. Guidelines for Management Planning of Protected Areas. IUCN: Gland, Switzerland and Cambridge, UK.

\section{Authors}

Annemarie Polderman - corresponding author ${ }^{1}$ is a geographer and holds a $\mathrm{PhD}$ from The Ohio State University. Her main interests are human-environment interactions and political ecology.

\section{Suzana Vurunić}

is a geographer and works at the Institute of the Republic of Slovenia for Nature Conservation (IRSNC). She holds a Master of Arts in Geography from the University of Ljubljana. Her main interests are ecosystem services and nature conservation.

\section{Nadine Houbé}

is a geographer and holds an MSc from the University of Innsbruck. Her research interests include geoinformatics, management of geodata, and web programming.

\section{Oliver Bender ${ }^{1}$}

is a senior scientist and head of the working group Man and Environment, Settlements. His research interests include cultural landscapes, and regional and urban development.

\section{Andreas Haller}

is a postdoctoral researcher and holds a $\mathrm{PhD}$ in Geography from the University of Innsbruck. His research interests include settlement geography and landscape research, with a focus on urbanization and land-use change.

${ }^{1}$ Institute for Interdisciplinary Mountain Research (IGF), Austrian Academy of Sciences (ÖAW) in Innsbruck, Austria.

This project is co-financed by the European Regional Development Fund through the Interreg Alpine Space programme. 